\title{
Dopaminergic Modulation of Sodium Current in Hippocampal Neurons via cAMP-Dependent Phosphorylation of Specific Sites in the Sodium Channel $\alpha$ Subunit
}

\author{
Angela R. Cantrell, ${ }^{1}$ Raymond D. Smith, ${ }^{2}$ Alan L. Goldin, ${ }^{2}$ Todd Scheuer, ${ }^{1}$ and William A. Catterall ${ }^{1}$ \\ ${ }^{1}$ Department of Pharmacology, University of Washington, Seattle, Washington 98195-7280, and ${ }^{2}$ Department of \\ Microbiology and Molecular Genetics, University of California, Irvine, California 92697
}

Phosphorylation of brain $\mathrm{Na}^{+}$channel $\alpha$ subunits by cAMPdependent protein kinase (PKA) decreases peak $\mathrm{Na}^{+}$current in cultured brain neurons and in mammalian cells and Xenopus oocytes expressing cloned brain $\mathrm{Na}^{+}$channels. We have studied PKA regulation of $\mathrm{Na}^{+}$channel function by activation of D1-like dopamine receptors in acutely isolated hippocampal neurons using whole-cell voltage-clamp recording techniques. The D1 agonist SKF 81297 reversibly reduced peak $\mathrm{Na}^{+}$current in a concentration-dependent manner. No changes in the voltage dependence or kinetics of activation or inactivation were observed. This effect was mediated by PKA, as it was mimicked by application of the PKA activator Sp-5,6-dichloro1 - $\beta$-D-ribofuranosylbenzimidazole-3',5'-monophosphorothioate (cBIMPS) and was inhibited by the specific PKA inhibitor peptide $\mathrm{PKAI}_{5-24}$. CBIMPS had similar effects on type IIA brain $\mathrm{Na}^{+}$ channel $\alpha$ subunits expressed in tsA-201 cells, but no effect was observed on a mutant $\mathrm{Na}^{+}$channel $\alpha$ subunit in which serine residues in five PKA phosphorylation sites in the intracellular loop connecting domains I and II $\left(L_{1-I I}\right)$ had been replaced by alanine. A single mutation, S573A, similarly eliminated cBIMPS modulation. Thus, activation of D1-like dopamine receptors results in PKA-dependent phosphorylation of specific sites in $\mathrm{L}_{1-\mid l}$ of the $\mathrm{Na}^{+}$channel $\alpha$ subunit, causing a reduction in $\mathrm{Na}^{+}$current. Such modulation is expected to exert a profound influence on overall neuronal excitability. Dopaminergic input to the hippocampus from the mesocorticolimbic system may exert this influence in vivo.

Key words: $\mathrm{Na}^{+}$current; neuromodulation; cAMP-dependent protein kinase; hippocampus; dopamine receptors; phosphorylation
Voltage-dependent $\mathrm{Na}^{+}$current is the primary inward current underlying excitability in the hippocampus and throughout the CNS but is not often recognized as a target for neuromodulation. The neuronal $\mathrm{Na}^{+}$channel $\alpha$ subunit is phosphorylated by cAMP-dependent protein kinase (PKA) (Costa et al., 1982; Costa and Catterall, 1984; Rossie and Catterall, 1987) on a family of sites in the intracellular loop connecting domains I and II (Rossie et al., 1987; Rossie and Catterall, 1989; Murphy et al., 1993). Activation of PKA reduces $\mathrm{Na}^{+}$flux in synaptosomes (Costa and Catterall, 1984) and peak $\mathrm{Na}^{+}$current in cultured rat brain neurons (Li et al., 1992). PKA also reduces current through type IIA brain $\mathrm{Na}^{+}$channels heterologously expressed in mammalian cells ( $\mathrm{Li}$ et al., 1992, 1993) or in Xenopus oocytes (Gershon et al., 1992; Smith and Goldin, 1996). These results suggest that $\mathrm{Na}^{+}$channels might be modulated by neurotransmitters coupled to signaling cascades that alter PKA activity.

Neuronal release of dopamine is a primary modulator of PKA activity in the CNS. In particular, the hippocampus receives a rich dopaminergic innervation from the mesocorticolimbic dopamine system (Meador-Woodruff et al., 1994). Five dopamine receptor subtypes (D1-D5) have been identified (Sibley and Monsma, 1992; Civelli et al., 1993; O’Dowd, 1993), and all are

Received June 26, 1997; accepted July 23, 1997.

This research was supported by National Institutes of Health Grant NS15751 to W.A.C., a National Institutes of Health postdoctoral fellowship from Training Grant T32 DA07278 and Individual Postdoctoral Fellowship NS10147 to A.R.C., and National Institutes of Health Grant NS26729 and an Established Investigator Award from the American Heart Association to A.L.G.

Correspondence should be addressed to Dr. William A. Catterall, Department of Pharmacology, University of Washington, Box 357280, Seattle, WA 98195-7280.

Copyright (C) 1997 Society for Neuroscience $0270-6474 / 97 / 177330-09 \$ 05.00 / 0$ expressed in the hippocampus (Meador-Woodruff et al., 1994). These may be broadly classified as D1-like (D1 and D5) or D2-like (D2-D4) (Stoof and Kebabian, 1981, 1984; Sibley and Monsma, 1992; O'Dowd, 1993). Both classes of receptor couple to adenylate cyclase, but with antagonistic effects. D1-like receptors stimulate adenylate cyclase activity, whereas D2-like receptors inhibit it (Stoof and Kebabian, 1981). Thus, activation of D1-like dopamine receptors could modulate $\mathrm{Na}^{+}$currents by activating PKA and phosphorylating the $\mathrm{Na}^{+}$channel $\alpha$ subunit in hippocampal pyramidal neurons. Activation of dopamine receptors reduces peak $\mathrm{Na}^{+}$current in rat neostriatal neurons through a PKA-dependent pathway (Surmeier et al., 1992; Schiffmann et al., 1995); however, no neurotransmitter receptor has been identified that activates PKA resulting in modulation of $\mathrm{Na}^{+}$channel activity in hippocampal pyramidal neurons.

We have examined modulation of $\mathrm{Na}^{+}$currents by D1-like dopamine receptors in acutely isolated rat hippocampal pyramidal neurons. Activation of D1-like dopamine receptors rapidly and reversibly reduces peak $\mathrm{Na}^{+}$current with no effect on the voltage dependence or kinetics of activation or inactivation. This effect requires the activation of PKA and is mimicked by the extracellular application of direct activators of PKA. Furthermore, we show that the modulation requires phosphorylation of serine 573 in the intracellular loop connecting homologous domains I and II $\left(\mathrm{L}_{\mathrm{I}-\mathrm{II}}\right)$ of the $\mathrm{Na}^{+}$channel $\alpha$ subunit. Dopaminergic input to the hippocampus from the mesocorticolimbic system may activate this pathway in vivo, thus contributing to the regulation of excitability in the hippocampus. A preliminary report of these results has been presented (Cantrell et al., 1996b). 


\section{MATERIALS AND METHODS}

Acute dissociation of hippocampal neurons. Hippocampal neurons from adult ( $>25 \mathrm{~d}$ postnatal) male rats were acutely isolated using procedures described previously (Bargas et al., 1995; Howe and Surmeier, 1995; Cantrell et al., 1996a). In brief, rats were decapitated under metofane anesthesia. Brains were quickly removed, iced, and blocked before slicing. Slices $(400-500 \mu \mathrm{m})$ were cut and transferred to a low-calcium (100 $\mu \mathrm{M}$ ), HEPES-buffered saline solution containing (in mM): 140 sodium isethionate, $2 \mathrm{KCl}, 4 \mathrm{MgCl}_{2}, 0.1 \mathrm{CaCl}_{2}, 23$ glucose, and $15 \mathrm{HEPES}, \mathrm{pH}$ 7.4, 300-305 mOsm/1. All solutions were bubbled with $100 \% \mathrm{O}_{2}$ before slicing. Slices were then incubated for $1-6 \mathrm{hr}$ in $\mathrm{NaHCO}_{3}$-buffered Earle's balanced salt solution (Sigma, St. Louis, MO) bubbled with $95 \%$ $\mathrm{O}_{2}$ and 5\% $\mathrm{CO}_{2}, \mathrm{pH} 7.4,300-305 \mathrm{mOsm} / 1$. Single slices were transferred to the low-calcium buffer. With the aid of a dissecting microscope, portions of the hippocampus were dissected and placed in a treatment chamber containing protease type XIV (Sigma; $0.7 \mathrm{mg} / \mathrm{ml}$ ) in HEPESbuffered HBSS (Sigma) at $35^{\circ} \mathrm{C}$, pH 7.4, 300-305 mOsm/l. After 5-10 min of enzyme treatment, the tissue was rinsed several times in the low-calcium buffer and mechanically dissociated using a series of firepolished Pasteur pipettes. The cell suspension was then plated into a 35 $\mathrm{mm}$ tissue culture dish (Corning, Corning, NY) mounted on the stage of an inverted microscope containing $1 \mathrm{ml}$ of HEPES-buffered, phosphatefree HBSS. After allowing the cells to settle (about $5 \mathrm{~min}$ ), the bathing solution was changed to normal external recording solution.

Mammalian cell transfection. tsA-201 cells, which are human embryonic kidney cells (HEK293 cells) that have been stably transfected with simian virus 40 large tumor antigen (Robert Dubridge, Cell Genesis, Foster City, CA), were used for transfection experiments. tsA-201 cells were maintained in DMEM/F12 medium (Life Technologies, Gaithersburg, MD) supplemented with $10 \%$ fetal calf serum (HyClone, Logan, UT), 25 $\mathrm{U}$ of penicillin $/ \mathrm{ml}$, and $25 \mu \mathrm{g}$ of streptomycin $/ \mathrm{ml}$ (Sigma). They were cotransfected with cDNA encoding the human CD8 marker protein (EBO-pCD-leu2; American Type Culture Collection, Rockville, MD) and a plasmid encoding either the wild-type (WT) rat brain type IIA $\mathrm{Na}^{+}$channel $\alpha$ subunit, a mutant $\mathrm{Na}^{+}$channel $\alpha$ subunit in which serines in each of the consensus PKA phosphorylation sites in $\mathrm{L}_{\text {I-II }}$ have been mutated to alanine $\left(\mathrm{PKA}_{\mathrm{TOT}}\right.$; designated PKACOMP-A by Smith and Goldin, 1996, 1997), or a mutant $\mathrm{Na}^{+}$channel $\alpha$ subunit in which serine 573 has been mutated to alanine (S573A). Cells were transfected using the calcium phosphate precipitation method as described previously (Margolskee et al., 1993). Successfully transfected cells were then identified with magnetic polystyrene microspheres coated with anti-CD8 antibody (Jurman et al., 1994; M-450 CD8 Dynabeads, Dynal, Great Neck, NY).

Whole-cell voltage-clamp recording. Whole-cell currents were recorded from pyramidally shaped hippocampal neurons that had at most one or two short processes or from tsA-201 cells expressing WT or mutant $\mathrm{Na}^{+}$ channel $\alpha$ subunits (Hamill et al., 1981; Bargas et al., 1995; Howe and Surmeier, 1995). Electrodes were pulled from $75 \mu \mathrm{l}$ micropipette glass (VWR Scientific, Westchester, PA) and fire-polished before use. A low $\mathrm{Na}^{+}$extracellular recording solution was used for recording from hippocampal neurons to reduce current magnitude. It contained (in $\mathrm{mM}$ ): 20 $\mathrm{NaCl}, 10 \mathrm{HEPES}, 1 \mathrm{MgCl}_{2}, 0.4 \mathrm{CdCl}_{2}, 55 \mathrm{CsCl}, 5 \mathrm{BaCl}_{2}$, and 80 glucose, $\mathrm{pH} 7.3$, with $\mathrm{NaOH}, 300-305 \mathrm{mOsm} / 1$. For recording from tsA-201 cells, the extracellular solution contained (in mM): $140 \mathrm{NaCl}, 10$ HEPES, 1 $\mathrm{MgCl}_{2}, 0.4 \mathrm{CdCl}_{2}, 25 \mathrm{CsCl}$, and $5 \mathrm{BaCl}_{2}, \mathrm{pH} 7.3$, with $\mathrm{NaOH}, 300-305$ $\mathrm{mOsm} / \mathrm{l}$. The intracellular recording solution contained (in mM): 189 $\mathrm{N}$-methyl D-glucamine, $40 \mathrm{HEPES}, 4 \mathrm{MgCl}_{2}, 1 \mathrm{NaCl}, 0.1 \mathrm{BAPTA}, 25$ phosphocreatine, 2-4 $\mathrm{Na}_{2} \mathrm{ATP}, 0.2 \mathrm{Na}_{3} \mathrm{GTP}$, and 0.1 leupeptin, $\mathrm{pH} 7.2$, with $\mathrm{H}_{2} \mathrm{SO}_{4}, 270-275 \mathrm{mOsm} / 1$. SKF 81297, SKF 38393, and SCH 23390 (Research Biochemicals, Natick, MA) were prepared as concentrated stocks in water and frozen in aliquots before use. Tetrodotoxin (TTX; Calbiochem, San Diego, CA), PKA inhibitor (PKAI) and PKC inhibitor (PKCI) (PKAI (2-24 $_{\text {and }} \mathrm{PKCI}_{19-36}$, respectively; Peninsula Labs, Belmont, $\mathrm{CA})$ were prepared as concentrated stocks in water and diluted immediately before recording. Sp-5,6-dichloro-1- $\beta$-D-ribofuranosylbenzimidazole3',5'-monophosphoro-thioate (cBIMPS; BioLog, LaJolla, CA) was prepared as a concentrated stock in DMSO and diluted before use. Appropriate vehicle controls were performed where necessary.

Electrode resistances were typically $3-6 \mathrm{M} \Omega$ in the bath. Recordings were obtained using an Axon Instruments (Foster City, CA) 1C patch clamp. Voltage pulses were delivered, and currents were recorded using a personal computer running Basic-FASTLAB software to control an analog-to-digital/digital-to-analog interface (IDA, Indec Systems, Capitola, CA). Series resistance compensation $(70-80 \%)$ was routinely used.
Pharmacological compounds were applied using a gravity-fed "sewer pipe" system. The array of application capillaries $(\sim 150 \mathrm{~mm}$ inner diameter) was positioned a few hundred micrometers away from the cell under study. Solutions were changed by altering the position of the array with a microprocessor-controlled DC motor (Newport-Klinger, Inc., Irvine, CA). Complete solution changes were achieved within $1 \mathrm{sec}$, as estimated from the rate of block by TTX or the rate of change in reversal potential after a solution change.

Pulse protocols and data analysis. Data were collected using standard voltage step protocols. Conductance $(g)$ was calculated from peak current measured during test pulses to varying voltages according to $g(V)=$ $I /\left(V-V_{\text {rev }}\right)$, where $I$ was the current, $V$ was the test pulse voltage, and $V_{\text {rev }}$ was the measured reversal potential. The voltage dependence of inactivation was measured using 20 -msec-long conditioning pulses to a varying potential followed by a test pulse to $-10 \mathrm{mV}$. Peak test pulse current was plotted as a function of conditioning pulse voltage. Both conductance-voltage and inactivation-voltage curves were fit with a Boltzmann function of the form:

$$
g(V)=g_{\text {max }} /\left\{1+\exp \left[\left(V-V_{\mathrm{h}}\right) / k\right]\right\},
$$

where $V_{\mathrm{h}}$ was the half-activation or inactivation voltage, $k$ was a slope factor, and $g_{\max }$ was the maximum conductance.

Dose-response curves were fit with a Langmuir isotherm of the form:

$$
I_{\text {peak }}=\left\{I_{\text {sensitive }}\left(1+[M] / \mathrm{EC}_{50}\right)^{-n}+I_{\text {resistant }}\right\},
$$

where $I_{\text {peak }}$ was the maximum current elicited by the pulse, $I_{\text {sensitive }}$ was the blockable current, $[M]$ was the agonist concentration, $\mathrm{EC}_{50}$ was the concentration of agonist producing $50 \%$ block, $I_{\text {resistant }}$ was the portion of the current resistant to modulation, and $n$ was usually set to 1 (varying $n$ between 0.5 and 1.5 did not significantly enhance the fits for the data described here). Least squares curve fitting and statistical analysis were done using Sigma Plot (Jandel Scientific, Corte Madera, CA). Statistics are presented as mean \pm SEM. When the sample sizes allowed, box plots of the data were drawn. In the box plot, the median is represented as the central bar of the box, the edges of the box are the interquartiles (technically fourths), and the "whiskers" are lines drawn to the most extreme points in the sample that are not outliers (defined as points beyond interquartile $\pm 1.5 \times$ interquartile range); outliers are shown as circles or asterisks (Tukey, 1977).

\section{RESULTS}

\section{$\mathrm{Na}^{+}$current in hippocampal neurons is modulated by activation of D1-like dopamine receptors}

As an initial step in studying dopaminergic modulation of $\mathrm{Na}^{+}$ channels by phosphorylation, we examined the effect of agonists of D1-like dopamine receptors. Whole-cell $\mathrm{Na}^{+}$currents were recorded in acutely dissociated hippocampal neurons using solutions that isolated voltage-dependent $\mathrm{Na}^{+}$current (see Materials and Methods). Under these recording conditions, all of the remaining voltage-dependent current was blocked by the specific $\mathrm{Na}^{+}$channel blocker TTX (see Cantrell et al., 1996a). Application of the D1-like dopamine receptor agonist SKF 81297 (Arnt et al., 1992) rapidly and reversibly inhibited the whole-cell $\mathrm{Na}^{+}$ current (Fig. 1A,B). Significant reductions in current were observed in $73.4 \%$ of the cells tested $(n=34)$. In the responding cells, saturating concentrations of SKF $81297(5 \mu \mathrm{M})$ reduced current an average of $22.2 \pm 1.7 \%(n=25)$. The magnitude of the response varied from cell to cell with a range of 7.1 to $36.8 \%$, as indicated by the box plot in Figure $1 B$, inset. Similar effects were observed for a second agonist, SKF 38393 (Fig. 1C,D). Saturating concentrations of this agonist $(5-10 \mu \mathrm{M})$ reduced current an average of $26.8 \pm 2.8 \%(n=10)$. These results are in good agreement with data previously reported for the modulation of $\mathrm{Na}^{+}$current by dopamine receptor agonists in the neostriatum (Surmeier et al., 1992; Schiffmann et al., 1995). To confirm that these effects were mediated via D1-like dopamine receptors, the concentration dependence of the effect and its sensitivity to specific antagonists were tested. The effects of SKF 81297 were 
Figure 1. D1-like dopamine receptor agonists reduce whole-cell $\mathrm{Na}^{+}$current. $A$, The absolute value of peak inward $\mathrm{Na}^{+}$current is plotted as a function of time during the experiment. The cell was exposed to SKF $81297(5 \mu \mathrm{M})$ by rapid perfusion during the period indicated by the solid bar. Test pulses to $-20 \mathrm{mV}$ (40 msec long) were applied once every $2 \mathrm{sec}$ from a holding potential of $-75 \mathrm{mV}$. The same pulse protocol was used in subsequent figures unless otherwise indicated. $B$, Representative current traces obtained under control conditions (1) and in the presence of SKF 81297 (2) recorded at the times indicated in $A$. Inset, Box plot showing the extent of current reduction in cells that responded to SKF 81297. C, Effect of SKF 38393 (10 $\mu \mathrm{M})$ on peak inward $\mathrm{Na}^{+}$current as described in $A$. D, Representative current traces obtained under control conditions (1) and in the presence of SKF 38393 (2) at the times indicated in $C$. Inset, Box plot showing the extent of reduction in cells that responded to SKF 38393.
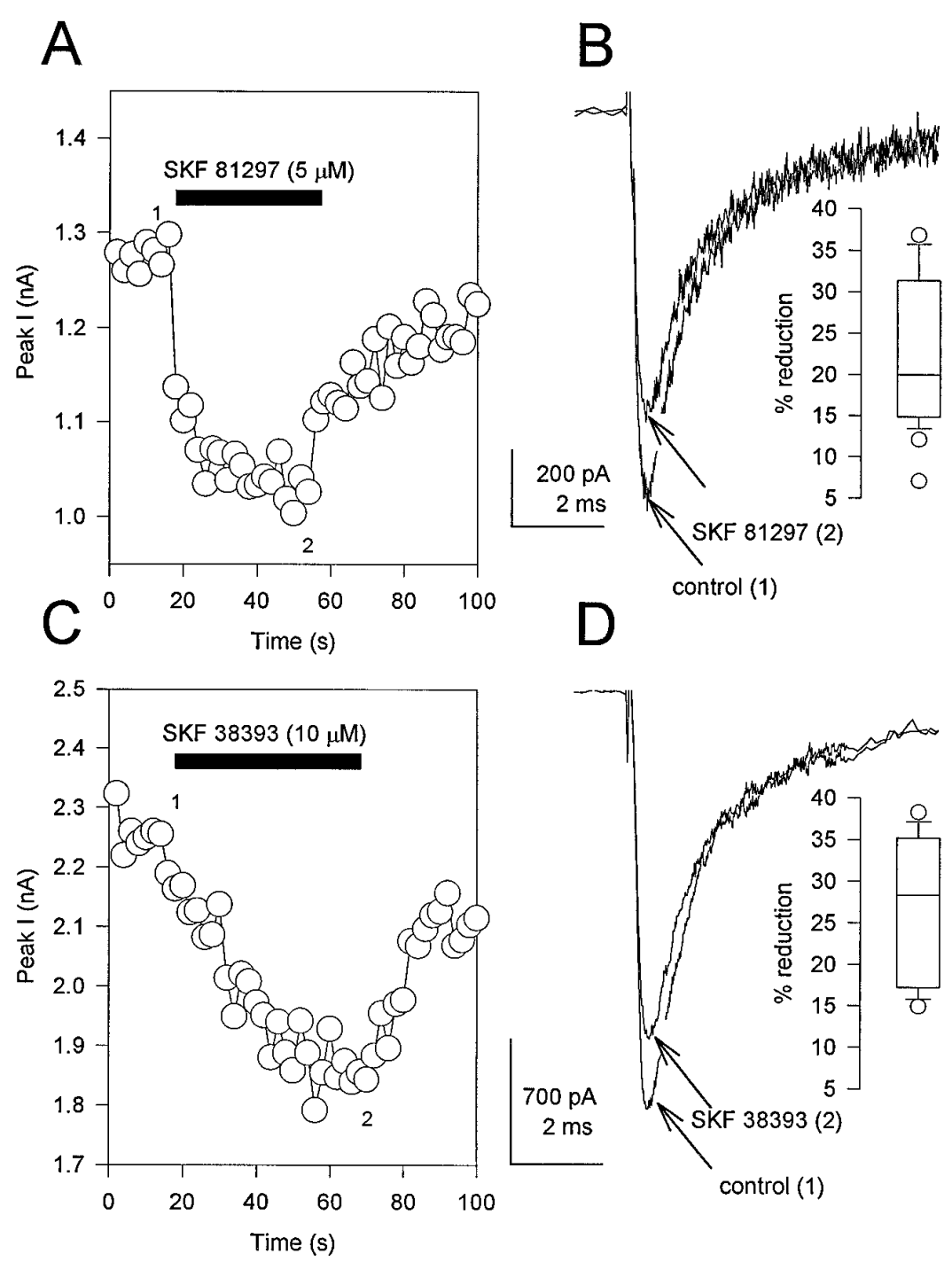

concentration-dependent, as shown in Figure $2 A, B$. Concentration-response plots for SKF 81297 were fit with a single Langmuir isotherm having a mean $\mathrm{IC}_{50}$ of $825.4 \pm 128.8 \mathrm{~nm}$ (Fig. $2 A$; $n=8$ independent experiments). Modulation by 5-10 $\mu \mathrm{M} \mathrm{SKF}$ 81297 was prevented in the presence of the D1-like dopamine receptor antagonist SCH $23390(10 \mu \mathrm{M}$; Fig. $2 C, D)$. It was recovered after SCH 23390 removal, confirming that the tested cell was responsive to SKF 81297. These results demonstrate that the observed effects were mediated by the activation of D1-like dopamine receptors. Similar effects of SCH 23390 were observed in four other experiments. Taken together, these data confirm that SKF 81297 acts at D1-like dopamine receptors on hippocampal pyramidal neurons to produce a dose-dependent reduction in tetrodotoxin-sensitive, voltage-dependent $\mathrm{Na}^{+}$current.

\section{Characterization of effects of D1-like dopamine receptor activation on $\mathrm{Na}^{+}$current properties}

The catalytic subunit of PKA was previously found to reduce peak $\mathrm{Na}^{+}$current in excised patches from cultured neurons with no discernible effects on the voltage dependence or kinetics of activation or inactivation ( $\mathrm{Li}$ et al., 1992). As a comparison with those results, we tested whether D1-like dopamine receptor agonists altered these properties of the current in hippocampal pyramidal neurons. The time course of $\mathrm{Na}^{+}$currents was similar before and after application of $5 \mu \mathrm{M}$ SKF 81297 (Figs. $1 B, 3 A-D$ ), and the reduction in peak $\mathrm{Na}^{+}$current was comparable at all test potentials (Fig. $3 A-E$ ). This indicates that the voltage dependence of activation of the $\mathrm{Na}^{+}$current was unchanged, as illustrated by the superimposition of current-voltage curves before and after agonist application (Fig. $3 E$ ). The half-activation voltage and slope factor in control conditions were $-44.2 \pm 5.3 \mathrm{mV}$ $(n=8)$ and $5.3 \pm 0.3 \mathrm{mV}(n=8)$, respectively, and $-44.9 \pm 5.4$ $\mathrm{mV}(n=8)$ and $5.5 \pm 0.3 \mathrm{mV}(n=8)$ in the presence of $5 \mu \mathrm{M}$ SKF 81297 (Fig. 3F,G). Likewise, the voltage dependence of inactivation during $50 \mathrm{msec}$ prepulses was also unaffected, having a half-inactivation voltage of $-51.8 \pm 1.5 \mathrm{mV}(n=13)$ and slope factor of $9.2 \pm 0.7 \mathrm{mV}(n=13)$ in control and a half-inactivation voltage of $-54.7 \pm 1.6 \mathrm{mV}$ and slope factor of $10.8 \pm 0.9 \mathrm{mV}(n=$ $13)$ in the presence of SKF $81297(n=13)$ (Fig. 3F, $G)$. Thus, the effects of D1-like receptor activation occur without dramatic alterations in the voltage-dependent properties of the $\mathrm{Na}^{+}$channel, consistent with the characteristics of $\mathrm{Na}^{+}$channel modulation by PKA (Li et al., 1992, 1993).

In previous experiments, the effects of PKA activation on brain $\mathrm{Na}^{+}$channels were studied by applying the purified catalytic subunit of PKA to the cytoplasmic surface of excised inside-out patches ( $\mathrm{Li}$ et al., 1992, 1993). To demonstrate that direct activa- 


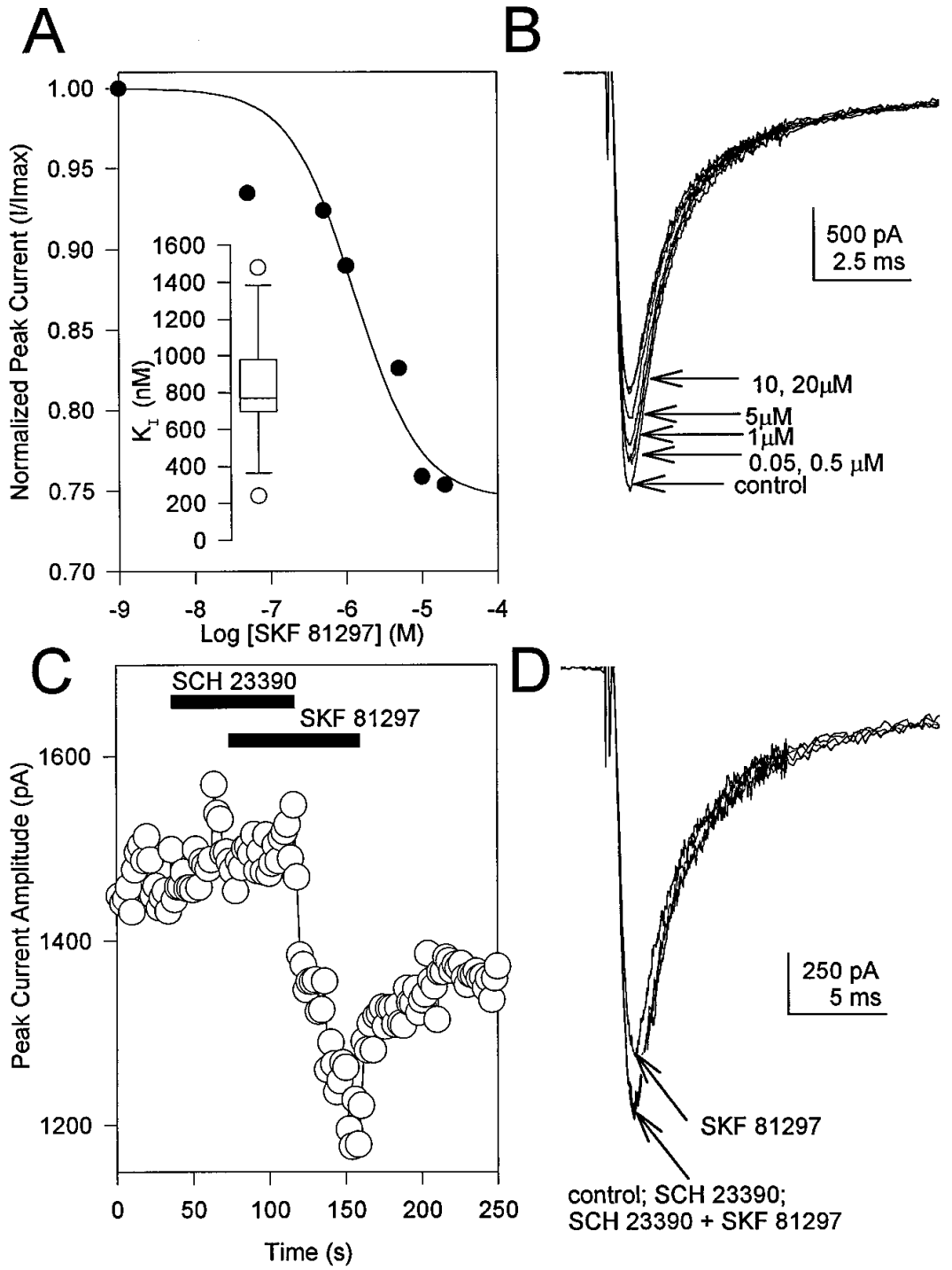

Figure 2. Involvement of a D1-like dopamine receptor in the signaling pathway. $A$, Dose-response curve for SKF 81297 reduction in current. The solid line is a least squares fit of a Langmuir isotherm to the data with $K_{\mathrm{I}}=745 \mathrm{nM}$. Inset, Box plot summarizing similar data from eight independent experiments. $B$, Representative current traces from the cell in $A$ obtained in control and in the presence of the indicated SKF 81297 concentrations. $C$, Peak $\mathrm{Na}^{+}$ current as a function of time as described for Figure $1 A$. The cell was first exposed to $10 \mu \mathrm{M} \mathrm{SCH} 23390$, then to a mixture of SCH 23390 and $10 \mu \mathrm{M}$ SKF 81297 , and finally to SKF 81297 alone, as indicated by the bars. $D$, Representative current traces from the experiment shown in $C$. tion of PKA produced the same effects as activation of D1-like dopamine receptors in hippocampal neurons, the modulation of $\mathrm{Na}^{+}$current by the potent and membrane-permeant activator of PKA cBIMPS (Sandberg et al., 1991) was studied. Application of cBIMPS (20-50 $\mu \mathrm{M})$ rapidly and reversibly reduced $\mathrm{Na}^{+}$currents in rat hippocampal neurons (Fig. 4A,B). Currents were reduced in all seven cells treated with $50 \mu \mathrm{M}$ cBIMPS, with a mean reduction of $21.7 \pm 4.5 \%$. Consistent with the preceding studies, the reduction in current attributable to activation of PKA occurred without changes in the voltage-dependent properties or kinetics in rat hippocampal neurons.

\section{The physiological effects of D1-like dopamine receptor activation require PKA}

To test directly for the involvement of PKA in the signaling pathway mediating the effects of D1-like dopamine receptor activation in hippocampal pyramidal neurons, we have used the specific peptide inhibitor of PKA, PKAI ${ }_{5-24}$ (Cheng et al., 1986). When $\mathrm{PKAI}_{5-24}$ was included in the pipette solution at a concentration of $10 \mu \mathrm{M}$, and 5-7 min were allowed for intracellular dialysis, SKF 81297 no longer modulated wholecell $\mathrm{Na}^{+}$current in hippocampal neurons (Fig. 5B). Although a slight increase in $\mathrm{Na}^{+}$current is observed for the cell in
Figure $5 B$, an average of results on six cells showed that SKF 81297 reduced peak current by $5.5 \pm 0.7 \%(p<0.006 ; n=6)$. During the same series of experiments, cells dialyzed with control internal solutions responded to SKF 81297 treatment with an average $\mathrm{Na}^{+}$current reduction of $22.1 \pm 4.2 \%(n=8$; Fig. $5 A$ ). The loss of SKF 81297 modulation was not attributable to loss of critical cellular components during the dialysis period, because a similar dialysis period was included in the control experiments. As an additional negative control for the effects of intracellular dialysis with a peptide fragment, we repeated the above experiment using the PKC-specific inhibitor peptide $\mathrm{PKCI}_{19-36}$ (House and Kemp, 1987). When $\mathrm{PKCI}_{19-36}$ was added to the pipette solution at a concentration of $2 \mu \mathrm{M}$, and 5-7 min were allowed for intracellular dialysis, a protocol sufficient to block $\mathrm{Na}^{+}$channel modulation by PKC (Cantrell et al., 1996a), $5 \mu \mathrm{M}$ SKF 81297 still reduced whole-cell $\mathrm{Na}^{+}$current an average of $28.2 \pm 10.5 \%(n=6$; Fig. $5 C)$. These data demonstrate that the block of SKF 81297 modulation by $\mathrm{PKAI}_{5-24}$ is attributable to the inhibition of PKA and not to nonspecific effects of the peptide itself. Consistent with this result, pre-exposure to $50 \mu \mathrm{M}$ cBIMPS to activate PKA occluded any further modulation by SKF 81297 (Fig. 4C,D; $n=5$ ). Thus, 
Figure 3. Voltage dependence of D1-like dopamine receptor effect on $\mathrm{Na}^{+}$currents. $A-D$, Whole-cell $\mathrm{Na}^{+}$current elicited by test pulses to the indicated potentials from a holding potential of $-75 \mathrm{mV}$ in the absence and presence of $5 \mu \mathrm{M}$ SKF 81297. In each panel, the smaller current was obtained in the presence of SKF 81297. E, Current-voltage relationship for peak $\mathrm{Na}^{+}$current in control (closed squares) and in the presence of SKF 81297 (closed circles). The SKF 81297 points have been scaled to facilitate comparison of the voltage dependence of the $\mathrm{Na}^{+}$current in the absence and presence of the compound (shaded triangle). $F$, Boltzmann fits of the activation and inactivation curves for the same cell in control (closed symbols) and in the presence of SKF 81297 (open symbols). G, Box plot showing the range of half-activation and half-inactivation voltages obtained in control and in the presence of SKF 81297.

activation of PKA is required for D1-like dopamine receptormediated reduction of $\mathrm{Na}^{+}$current in hippocampal neurons.

\section{Modulation of $\mathrm{Na}^{+}$current by PKA requires phosphorylation of the $\mathrm{Na}^{+}$channel $\alpha$ subunit in one or more identified PKA sites in $\mathrm{L}_{1-I I}$}

The next set of experiments examined the molecular substrate for the PKA phosphorylation initiated by activation of the D1-like dopamine receptor. The $\alpha$ subunit of the neuronal $\mathrm{Na}^{+}$channel is phosphorylated at up to four sites by PKA in intact neurons (Rossie and Catterall, 1987). Serine residues 573, 610, 623, and 687 are phosphorylated by PKA both in vitro and in intact cells (Rossie et al., 1987; Rossie and Catterall, 1989; Murphy et al., 1993). A mutant channel in which each of these serines plus nearby serine 554 had been mutated to alanine was resistant to the effects of PKA activation when expressed in Xenopus oocytes (Smith and Goldin, 1996). Because there may be significant differences between PKA modulation in Xenopus oocytes and mammalian cells, it was important to determine that these same sites were responsible for the modulatory effects of PKA in mammalian cells under the conditions we had used to activate PKA in hippocampal neurons. For these experiments, we used the same mutant type IIA rat brain $\mathrm{Na}^{+}$channel $\alpha$ subunit in which the serine residues in each of the identified PKA sites had been mutated to alanine $\left(\mathrm{PKA}_{\mathrm{TOT}}\right.$; designated PKACOMP-A by Smith and Goldin, 1996). Plasmids
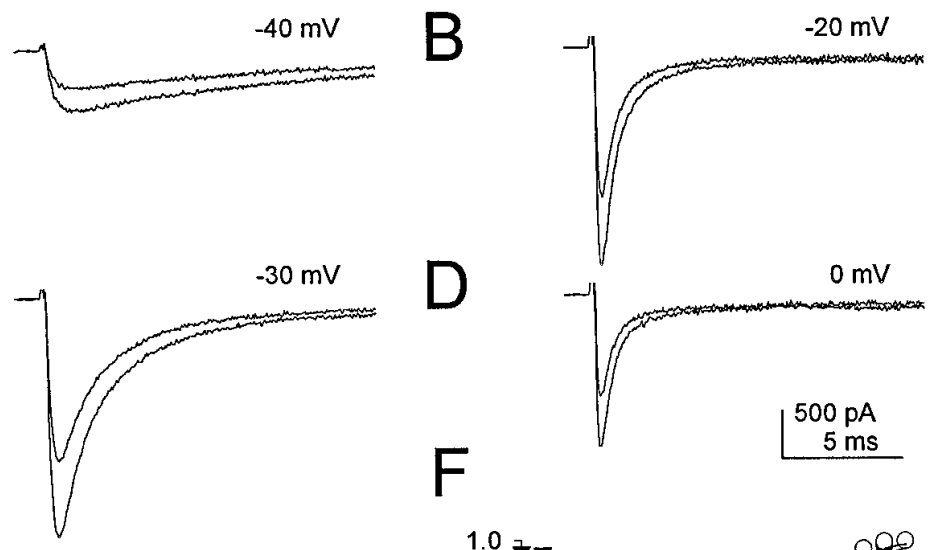

$I(n A)$
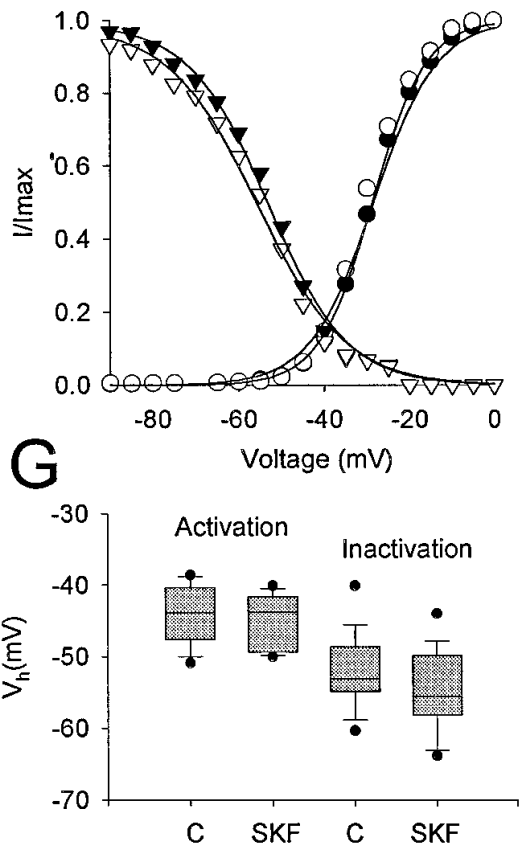

containing cDNA encoding either $\mathrm{WT}$ or $\mathrm{PKA}_{\mathrm{TO}}$ mutant rat brain type IIA $\mathrm{Na}^{+}$channel $\alpha$ subunits were transiently expressed in the tsA-201 cell subclone of HEK293 cells. Application of 20 and $50 \mu \mathrm{M}$ cBIMPS to tsA-201 cells expressing WT type IIA $\mathrm{Na}^{+}$ channel $\alpha$ subunits reduced the expressed $\mathrm{Na}^{+}$current in a concentration-dependent manner (Fig. 6A,B). The mean reduction by $50 \mu \mathrm{M}$ cBIMPS in these cells was $21.3 \pm 2.3 \%(n=25$; Fig. $6 F)$. In contrast, the mutant $\mathrm{Na}^{+}$channel PKA $\mathrm{TOT}_{\text {TO }}$ was not modulated by cBIMPS application (Fig. $6 C, D, F$ ). The mean reduction was $2.7 \pm 0.9 \%(50 \mu \mathrm{M} ; n=16 ; p<0.0005$, Student's $t$ test) (Fig. $6 F)$. Recent work has indicated that the PKA site centered at serine 573 is required to mediate the effects of PKA on rat brain type IIA $\mathrm{Na}^{+}$channels expressed in Xenopus oocytes (Smith and Goldin, 1997). To test whether the same site is required for PKA modulation when the channel is expressed in mammalian cells, we used a mutant type IIA rat brain $\mathrm{Na}^{+}$channel $\alpha$ subunit in which serine 573 had been mutated to alanine (S573A). When transiently expressed in tsA-201 cells, mutant S573A channels were also not modulated significantly by cBIMPS application (Fig. 6E,F). The mean reduction was $3.9 \pm 2.1 \%(50 \mu \mathrm{M} ; n=11 ; p<0.0005$, Student's $t$ test) (Fig. 6F). These experiments demonstrate that PKA-dependent modulation of neuronal $\mathrm{Na}^{+}$channels expressed in mammalian cells requires phosphorylation of serine 573 of the $\mathrm{Na}^{+}$channel $\alpha$ subunit. 


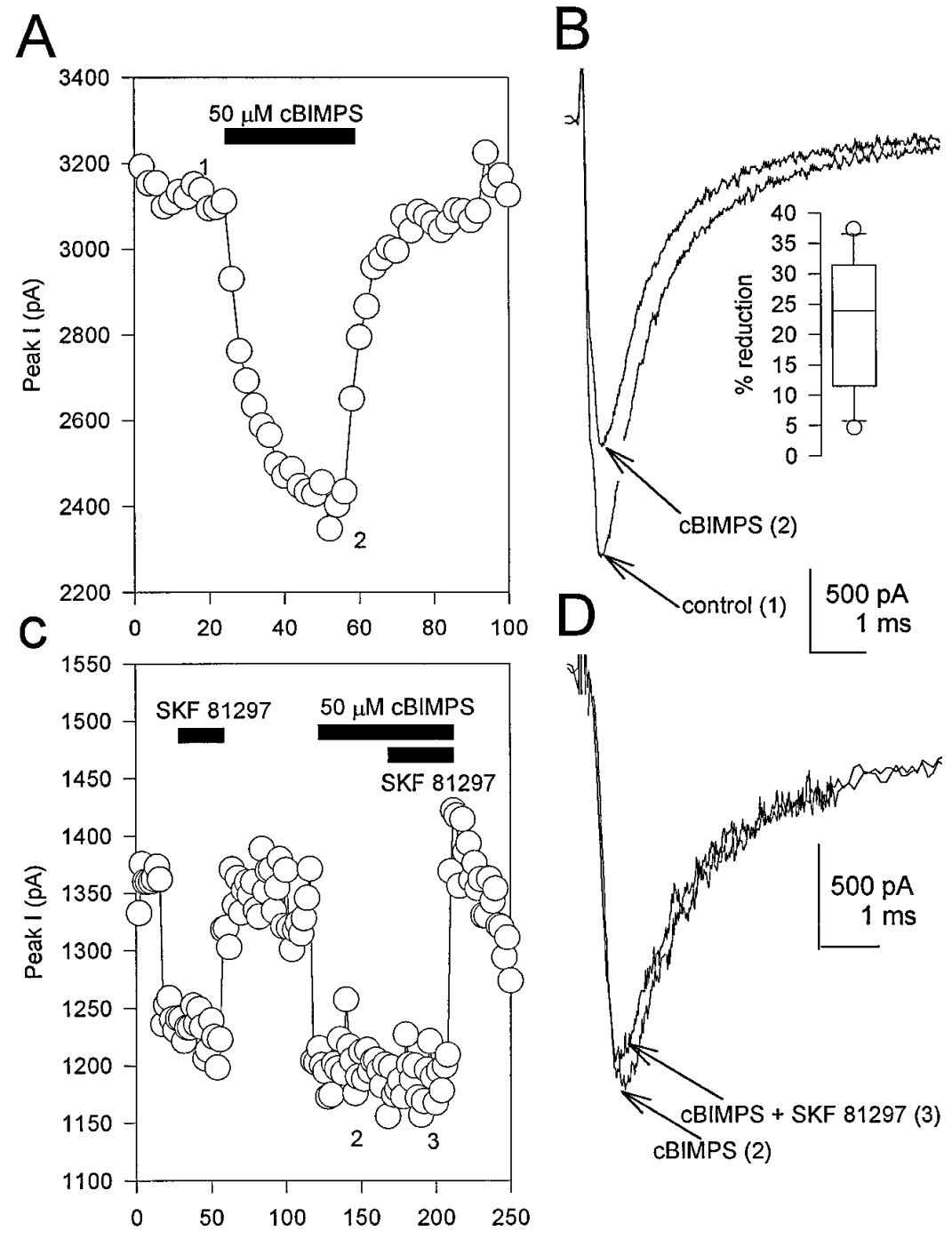

Figure 4. Reduction of $\mathrm{Na}^{+}$current by PKA activation. $A$, Peak $\mathrm{Na}^{+}$currents elicited in control and in the presence of $50 \mu \mathrm{M}$ cBIMPS plotted as a function of time during the experiment. $B$, Representative current traces in control (1) and in the presence of cBIMPS (2) recorded at the times indicated in $A$. Inset, Box plot showing the extent of current reduction in response to cBIMPS. $C$, Peak $\mathrm{Na}^{+}$currents plotted as a function of time. The cell was first exposed to $5 \mu \mathrm{M}$ SKF 81297, then $50 \mu \mathrm{M}$ cBIMPS, and finally to a mixture of SKF 81297 and cBIMPS as indicated by the bars. The time course was corrected for a $20 \%$ rundown in the currents by subtraction of an exponential fit to the currents during control periods. $D$, Representative current traces in cBIMPS (2) and in the presence of cBIMPS plus SKF 81297 (3) recorded at the times indicated in $C$.

\section{DISCUSSION}

\section{Activation of D1-like dopamine receptors in hippocampal pyramidal neurons reduces $\mathrm{Na}^{+}$current via phosphorylation of the $\mathrm{Na}^{+}$channel by PKA}

This study describes a complete signaling pathway linking activation of a neurotransmitter receptor on the cell surface of a neuron to PKA-dependent phosphorylation of a specific site on the $\mathrm{Na}^{+}$channel $\alpha$ subunit for the first time. Earlier work had shown that $\mathrm{Na}^{+}$currents in cultured rat brain neurons and in mammalian cell lines expressing the $\alpha$ subunit of the rat brain type IIa $\mathrm{Na}^{+}$channel were reduced by application of the catalytic subunit of PKA to the cytoplasmic surface of excised patches of membrane (Li et al., 1992). That reduction occurred without significantly altering the voltage-dependent properties of the channel or its rate of inactivation. The present work demonstrates that D1-like dopamine receptor activation in acutely isolated hippocampal neurons produces a similar modulation of $\mathrm{Na}^{+}$current and that the modulation requires activation of PKA. Furthermore, we show that PKAdependent reduction of $\mathrm{Na}^{+}$current is abolished in a mutant $\mathrm{Na}^{+}$channel $\alpha$ subunit in which each of the serines in PKA consensus sites that have been shown to be phosphorylated by PKA in biochemical experiments (Rossie et al., 1987; Rossie and Catterall, 1989; Murphy et al., 1993) has been mutated to alanine (Smith and Goldin, 1996, 1997), as well as in the single serine mutant S573A. Thus, the reduction in $\mathrm{Na}^{+}$current by activation of D1-like dopamine receptors requires phosphorylation of serine 573. Experiments with other single-site mutants will be required to determine whether the other phosphorylated serine residues may also have significant effects in mammalian cells. In Xenopus oocytes, phosphorylation of serines 610 and 623 has a small effect, whereas phosphorylation of serines 554 and 687 has none (Smith and Goldin, 1997).

There have been few reports of receptor-mediated modulation of $\mathrm{Na}^{+}$channel activity in neurons. $\mathrm{Na}^{+}$currents in Aplysia neurons are modulated by the peptide FMRFamide (Brussaard et al., 1991), but the mechanism of receptor coupling to $\mathrm{Na}^{+}$channel modulation is unknown. Consistent with the present results in hippocampal neurons, activation of dopaminergic receptors modulates whole-cell $\mathrm{Na}^{+}$current in neostriatal neurons via a PKAdependent signaling pathway (Surmeier et al., 1992; Schiffmann et al., 1995). Because striatal neurons are specialized for response to dopaminergic neurotransmission, and dopamine has regulatory effects in them that are not observed in other neurons, extension of this regulatory mechanism for $\mathrm{Na}^{+}$channels to hippocampal neurons suggests that it may be a widely distributed component of 


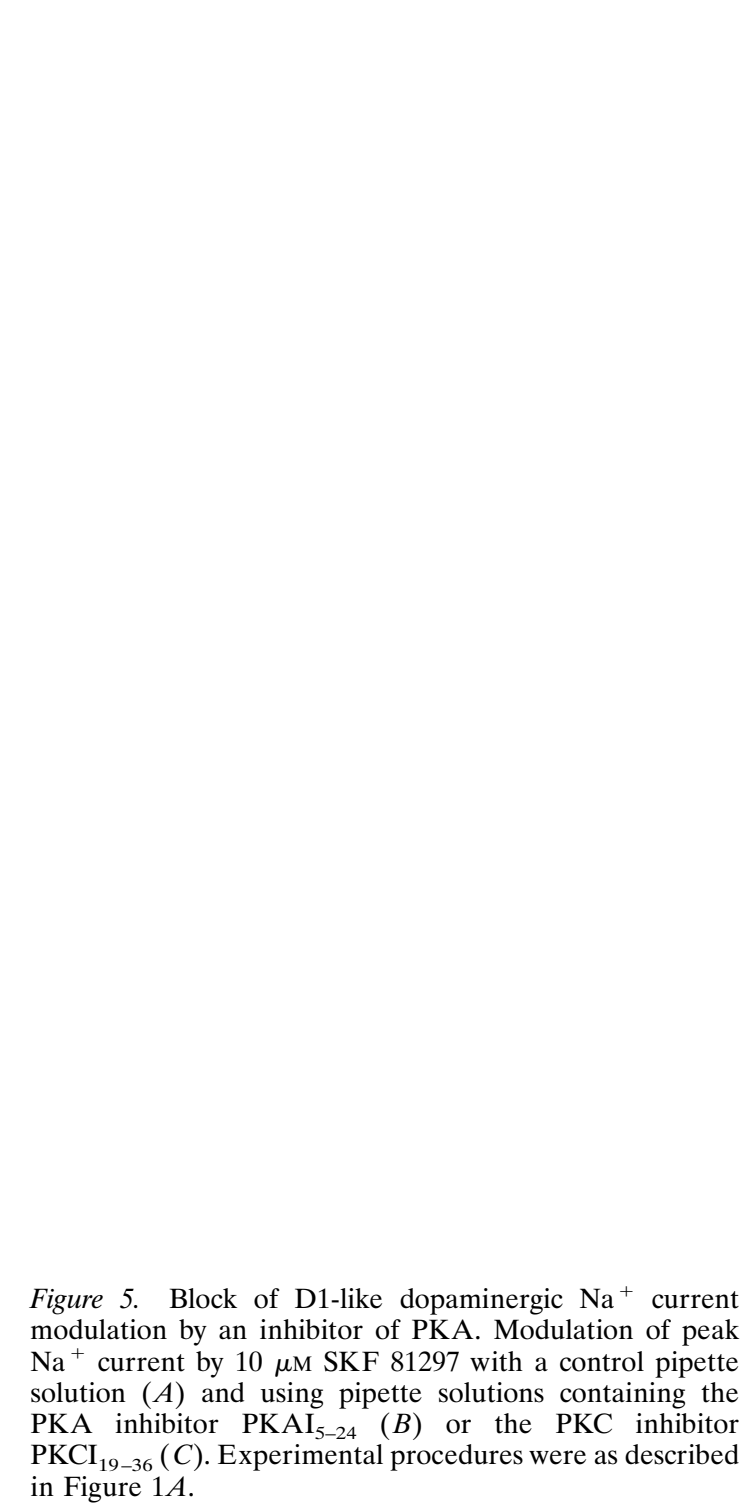

modulation by an inhibitor of PKA. Modulation of peak $\mathrm{Na}^{+}$current by $10 \mu \mathrm{M}$ SKF 81297 with a control pipette PKCI $_{19-36}(C)$. Experimental procedures were as described in Figure $1 A$

the response to dopamine and other neurotransmitters that activate adenylate cyclase.

In hippocampal neurons work from our laboratory has previously shown that activation of muscarinic receptors modulates whole-cell $\mathrm{Na}^{+}$current (Cantrell et al., 1996a). Those effects occur by a pathway requiring activation of $\mathrm{PKC}$ but not activation of PKA. The dopaminergic pathway described here is a distinct pathway for $\mathrm{Na}^{+}$channel modulation that is distinguished by its dependence on PKA phosphorylation. Thus, two biochemically distinct pathways for $\mathrm{Na}^{+}$current modulation by neurotransmitters are present in hippocampal neurons.

The effects of PKA activation on $\mathrm{Na}^{+}$currents demonstrated in the present paper are similar to previous results using cultured rat brain cells or expressed rat brain type IIA $\mathrm{Na}^{+}$channel $\alpha$ subunits ( $\mathrm{Li}$ et al., 1992, 1993). A notable exception is that phosphorylation of Ser1506 in the intracellular loop connecting homologous domains III and IV by PKC was required to observe measurable PKA-dependent modulation in a mammalian cell line in the previous study ( $\mathrm{Li}$ et al., 1993). In the present work, PKA-dependent modulation was not blocked by inclusion of the peptide inhibitor of $\mathrm{PKC}, \mathrm{PKCI}_{19-36}$, in the recording pipette. We have found that this difference in the requirement for PKC activity to observe inhibition of $\mathrm{Na}^{+}$currents by activation of PKA is caused by differences in the holding potential in the two studies (Cantrell et al., 1997). At a holding potential of $-110 \mathrm{mV}$, as used in the studies of Li et al. (1993), little effect of PKA on $\mathrm{Na}^{+}$current is observed unless $\mathrm{PKC}$ is also activated. At more positive holding potentials, the requirement for PKC activation is progressively reduced and is insignificant at the holding potential of $-75 \mathrm{mV}$ used here. These results show that the convergent regulation of $\mathrm{Na}^{+}$channels by the PKA and PKC pathways is voltage-dependent. The voltage dependence of these effects of phosphorylation provides an additional element of specificity and sensitivity to modulation of brain $\mathrm{Na}^{+}$channels.

\section{Dopaminergic receptor subtypes responsible for modulation}

All five of the known dopamine receptor subtypes are expressed in the hippocampus (Meador-Woodruff et al., 1994). The D1-like (D1 and D5) dopamine receptors stimulate adenylate cyclase and increase PKA activity (Stoof and Kebabian, 1981, 1984; Sibley and Monsma, 1992; O'Dowd, 1993). Although we have not yet 


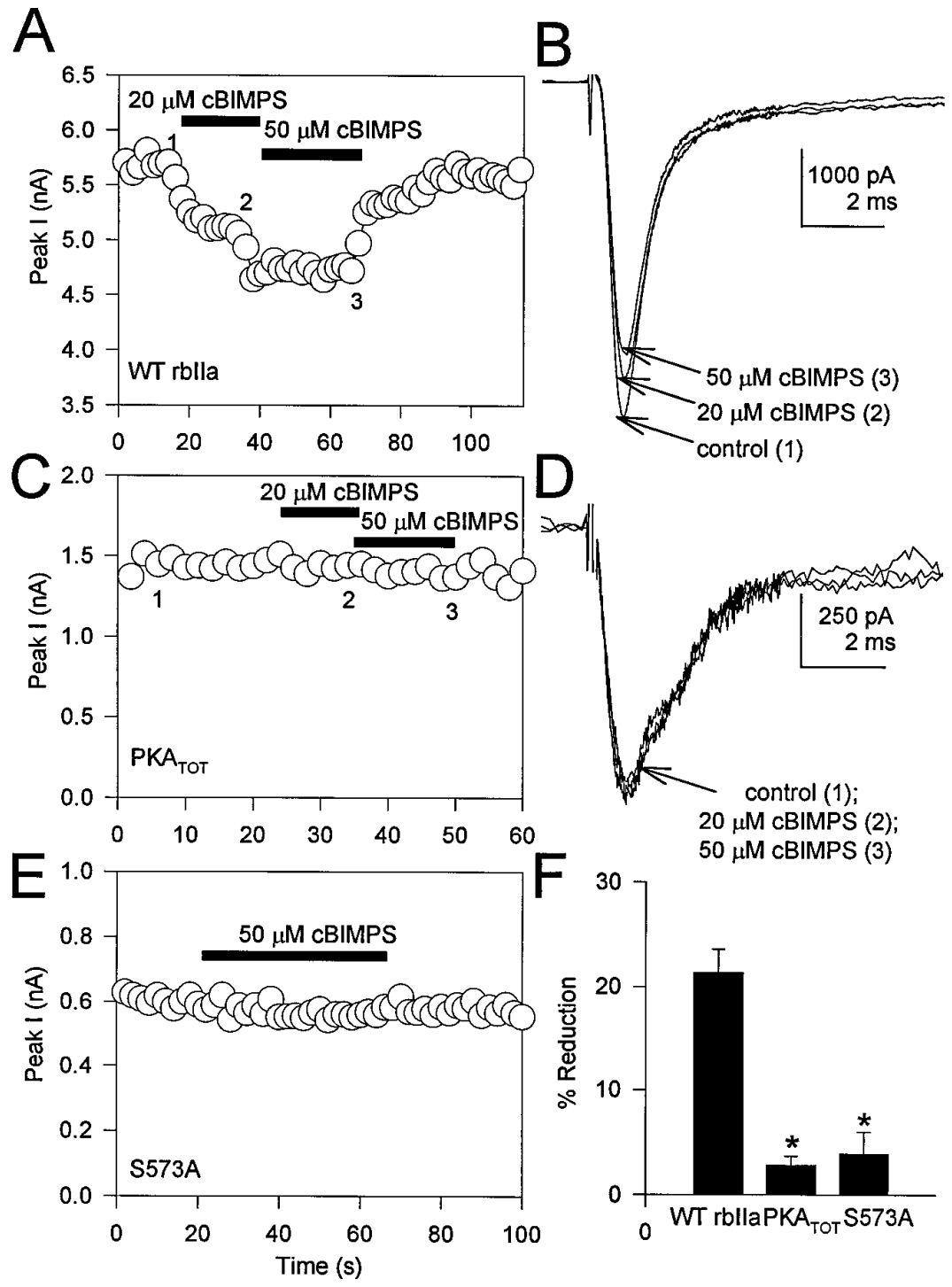

Figure 6. Modulation by PKA activation requires direct phosphorylation of the $\mathrm{Na}^{+}$channel $\alpha$ subunit. $A$, tsA-201 cell expressing WT rat brain type IIA $\alpha$ subunits was exposed to cBIMPS $(20-50 \mu \mathrm{M})$ during the periods indicated by the solid bars. B, Representative current traces obtained under control conditions (1) and in the presence of cBIMPS $(2,3)$ at the times indicated in $A$. The absolute value of peak inward $\mathrm{Na}^{+}$current is plotted as a function of time during the experiment. $C$, A tsA-201 cell expressing expressing mutant $\mathrm{PKA}_{\mathrm{TOT}}$ was exposed to cBIMPS $(20-50 \mu \mathrm{M})$ during the periods indicated by the solid bars. The absolute value of peak inward $\mathrm{Na}^{+}$current is plotted as a function of time during the experiment. $D$, Representative current traces obtained under control conditions (1) and in the presence of cBIMPS $(2,3)$ at the times indicated in C.E, A tsA-201 cell expressing expressing mutant S573A was exposed to cBIMPS $(50 \mu \mathrm{M})$ during the periods indicated by the solid bar. The absolute value of peak inward $\mathrm{Na}^{+}$current is plotted as a function of time during the experiment. $F$, Bar graphs showing the response to $50 \mu \mathrm{M}$ cBIMPS in tsA-201 cells expressing WT, $\mathrm{PKA}_{\mathrm{TOT}}$, or S573A mutant $\mathrm{Na}^{+}$channels.

determined which receptor subtype is responsible for mediating the effects we observe, the D1 and D5 dopamine receptor subtypes are good candidates for mediating the PKA-dependent reduction of $\mathrm{Na}^{+}$current that we have characterized in hippocampal pyramidal neurons. A more detailed determination, however, must await the development and availability of better subtype-specific blockers.

\section{Functional implications of $\mathrm{Na}^{+}$channel modulation through D1-like dopamine receptors in the hippocampus}

The hippocampus receives a rich dopaminergic innervation from the mesocorticolimbic dopamine system, and multiple dopamine receptor subtypes are expressed on the cell surface of hippocampal pyramidal neurons (Civelli et al., 1993; Meador-Woodruff et al., 1994). The effects of dopamine in the hippocampus are primarily inhibitory, resulting in elevation of spike threshold, slower firing rates, and in some cases membrane hyperpolarization (Biscoe and Straughan, 1966; Herrling, 1981; Stanzione et al., 1984; Pockett, 1985; Malenka and Nicoll, 1986; Berretta et al., 1990). Although it is currently postulated that these effects are primarily a consequence of enhancement of a slow $\mathrm{Ca}^{2+}$ dependent $\mathrm{K}^{+}$conductance (Bernardo and Prince, 1982; Hass and Konnerth, 1983; Pockett, 1985; Malenka and Nicoll, 1986), it is likely that these effects are mediated by a concerted action of the transmitter on several conductances including the $\mathrm{Na}^{+}$channel. Reduction of neuronal $\mathrm{Na}^{+}$currents would be expected to influence the excitability of the target neurons strongly. For example, reduction of peak $\mathrm{Na}^{+}$current would be expected to shift the voltage threshold for action potential generation toward more depolarized potentials. Thus, a stronger depolarization would be required to elicit a response. The frequency at which the cell is capable of generating action potentials might also be reduced. Additionally, reduction in peak $\mathrm{Na}^{+}$current by PKA could serve as a neuroprotective safeguard, preventing excitotoxicity resulting from prolonged hyperexcitability. The effects of activation of D1-like receptors are consistent with a role for modulation of $\mathrm{Na}^{+}$currents as an important contributing factor to the inhibitory effects of dopamine in the hippocampus.

\section{REFERENCES}

Arnt J, Hyttel J, Sánchez C (1992) Partial and full dopamine $\mathrm{D}_{1}$ receptor agonists in mice and rats: relation between behavioral effects and stimulation of adenylate cyclase activity in vitro. Eur J Pharmacol 213:259-267.

Bargas J, Howe A, Eberwine J, Cao Y, Surmeier DJ (1995) Cellular and 
molecular characterization of $\mathrm{Ca}^{2+}$ currents in acutely-isolated, adult rat neostriatal neurons. J Neurosci 14:6667-6686.

Bernardo LS, Prince DA (1982) Dopamine modulates a $\mathrm{Ca}^{2+}$ activated potassium conductance in mammalian hippocampal pyramidal cells. Nature 297:76-79.

Berretta N, Berton F, Bianchi R, Capogna M, Francesconi W, Brunelli M (1990) Effects of dopamine, D-1 and D-2 dopaminergic agonists on the excitability of hippocampal CA1 pyramidal cells in guinea pig. Exp Brain Res 83:124-130.

Biscoe TJ, Straughan DW (1966) Microiontophoretic studies of neurones in the cat hippocampus. J Physiol (Lond) 183:341-359.

Brussaard AB, Lodder JC, Maat AT, De Vlieger TA, Kits KS (1991) Inhibitory modulation by FMRFamide of the voltage-gated sodium current in identified neurons in Lymnaea stagnalis. J Physiol (Lond) 441:385-404.

Cantrell AR, Ma JY, Scheuer T, Catterall WA (1996a) Muscarinic modulation of sodium current by activation of protein kinase $\mathrm{C}$ in rat hippocampal neurons. Neuron 16:1019-1026.

Cantrell AR, Scheuer T, Catterall WA (1996b) Dopamine modulates sodium current via PKA activation in rat hippocampal neurons. Soc Neurosci Abstr 22:57.

Cantrell AR, Scheuer T, Catterall WA (1997) Reduction of brain $\mathrm{Na}^{+}$ current by activation of D1-like dopamine receptors is potentiated by depolarization and activation of protein kinase C. Soc Neurosci Abstr, in press.

Cheng HC, Kemp BE, Pearson RB, Smith AJ, Misconi L, VanPatten SM, Walsh DA (1986) A potent inhibitor of the cAMP-dependent protein kinase. J Biol Chem 261:989-992.

Civelli O, Bunzow JR, Grandy DK (1993) Molecular diversity of the dopamine receptors. Annu Rev Pharmacol Toxicol 32:281-307.

Costa MR, Catterall WA (1984) Cyclic AMP-dependent phosphorylation of the $\alpha$ subunit of the sodium channel in synaptic nerve ending particles. J Biol Chem 259:8210-8218.

Costa MR, Casnellie JE, Catterall WA (1982) Selective phosphorylation of the $\alpha$ subunit of the sodium channel by cAMP-dependent protein kinase. J Biol Chem 257:7918-7921.

Gershon E, Weigl L, Lotan I, Schreibmayer W, Dascal N (1992) Protein kinase A reduces voltage-dependent $\mathrm{Na}^{+}$current in Xenopus oocytes. J Neurosci 12:3743-3752.

Hamill OP, Marty A, Neher E, Sakman B, Sigworth FC (1981) Improved patch-clamp techniques for high-resolution current recording from cells and cell-free membrane patches. Pflügers Arch 391:85-100

Hass HL, Konnerth A (1983) Histamine and noradrenaline decrease calcium-activated potassium conductance in hippocampal pyramidal cells. Nature 302:432-434.

Herrling PL (1981) The membrane potential of cat hippocampal neurons recorded in vivo displays four different reaction mechanisms to iontophoretically applied transmitter agonists. Brain Res 212:331-343.

House C, Kemp BE (1987) Protein kinase C contains a pseudosubstrate prototype in its regulatory subunit. Science 238:1726-1728.

Howe AR, Surmeier DJ (1995) Muscarinic receptors modulate N-, P-, and L-type calcium currents in rat striatal neurons through parallel pathways. J Neurosci 15:458-469.

Jurman ME, Boland LM, Liu Y, Yellen G (1994) Visual identification of individual transfected cells for electrophysiological recording. Biotechniques 17:876-881.

Li M, West JW, Lai Y, Scheuer T, Catterall WA (1992) Functional modulation of brain sodium channels by cAMP-dependent phosphorylation. Neuron 8:1151-1159.
Li M, West JW, Numann R, Murphy BJ, Scheuer T, Catterall WA (1993) Convergent regulation of sodium channels by protein kinase $\mathrm{C}$ and cAMP-dependent protein kinase. Science 261:1439-1442.

Malenka RC, Nicoll RA (1986) Dopamine decreases the calciumactivated afterhyperpolarization in hippocampal CA1 pyramidal neurons. Brain Res 379:210-215.

Margolskee RF, McHendry-Rinde B, Horn R (1993) Panning transfected cells for electrophysiological studies. Biotechniques 15:906-911.

Meador-Woodruff JH, Grandy DK, Van Tol HHM, Damask SP, Little KY, Civelli O, Watson SJ (1994) Dopamine receptor gene expression in the human medial temporal lobe. Neuropsychopharmacology 10:239-248.

Murphy BJ, Rossie S, De Jongh KS, Catterall WA (1993) Identification of the sites of selective phosphorylation and dephosphorylation of the rat brain sodium channel $\alpha$ subunit by cAMP-dependent protein kinase and phosphoprotein phosphatases. J Biol Chem 268:27355-27362.

O'Dowd BF (1993) Structures of dopamine receptors. J Neurochem 60:804-816.

Pockett S (1985) Dopamine changes the shape of action potentials in hippocampal pyramidal cells. Brain Res 342:386-390.

Rossie S, Catterall WA (1987) Cyclic AMP-dependent phosphorylation of voltage-sensitive sodium channels in primary cultures of rat brain neurons. J Biol Chem 262:12735-12744.

Rossie S, Catterall WA (1989) Phosphorylation of the $\alpha$ subunit of rat brain sodium channels by cAMP-dependent protein kinase at a new site containing Ser686 and Ser687. J Biol Chem 264:14220-14224.

Rossie S, Gordon D, Catterall WA (1987) Identification of an intracellular domain of the sodium channel having multiple cAMP-dependent phosphorylation sites. J Biol Chem 262:17530-17535.

Sandberg M, Butt E, Nolte C, Fischer L, Halbrugge M, Beltman J, Jahnsen T, Genieser HG, Jastorff B, Walter U (1991) Characterization of Sp-5,6-dichloro-1-beta-D-ribof uranosylbenzimidazole- $3^{\prime}, 5^{\prime}$ monophosphorothioate (Sp-5,6-DCl-cBiMPS) as a potent and specific activator of cyclic-AMP-dependent protein kinase in cell extracts and intact cells. Biochem J 279:521-527.

Schiffmann SN, Lledo PM, Vincent JD (1995) Dopamine D1 receptor modulates the voltage-gated sodium current in rat striatal neurones through a protein kinase A. J Physiol (Lond) 483.1:95-107.

Sibley DR, Monsma FJ (1992) Molecular biology of dopamine receptors. Trends Pharmacol Sci 13:61-75.

Smith RD, Goldin AL (1996) Phosphorylation of brain sodium channels in the I-II linker modulates channel function in Xenopus oocytes. J Neurosci 16:1965-1974.

Smith RD, Goldin AL (1997) Phosphorylation at a single site in the brain sodium channel is necessary and sufficient for current reduction by protein kinase A. J Neurosci 17:6086-6093.

Stanzione P, Calabresi P, Mercuri N, Bernardi G (1984) Dopamine modulates CA1 hippocampal neurons by elevating the threshold for spike generation: an in vitro study. J Neurosci 13:1105-1116.

Stoof JC, Kebabian JW (1981) Opposing roles for D1 and D2 dopamine receptors in the efflux of cyclic AMP from rat neostriatum. Nature 294:366-368.

Stoof JC, Kebabian JW (1984) Two dopamine receptors: biochemistry, physiology and pharmacology. Life Sci 35:2281-2296.

Surmeier DJ, Eberwine J, Wilson CJ, Stefani A, Kitai ST (1992) Dopamine receptor subtypes co-localize in rat striatonigral neurons. Proc Natl Acad Sci USA 89:10178-10182.

Tukey JW (1977) Exploratory data analysis. Menlo Park, CA: Addison-Wesley. 